\title{
Breast cancer and anaesthesia: genetic influence
}

\author{
Aida Raigon Ponferrada ${ }^{a-b}$, Juan Carlos Molina Ruiz ${ }^{b}$, Salvador Romero \\ Molina $^{b}$, Jose Cruz Mañas ${ }^{b}$,Jose Luis Guerrero Orriach ${ }^{a-c^{*}}$
}

${ }^{*}$ Corresponding Author:

Guerrero Orriach JL

guerreroorriach@gmail.com

Anesthesia Deparment

HU Virgen de la Victoria

Campus Teatinos SN

Malaga

Spain

$1 \mathrm{a}_{\text {Institute of Biomedical Research in Malaga (IBIMA), Malaga, Spain }}$
$2 \mathrm{~b}_{\text {Department of Anesthesiology, Virgen de la Victoria University Hospital, Malaga, Spain }}$
$*{ }^{\mathrm{c}}$ Department of Pharmacology and Pediatrics, School of Medicine, University of Malaga, Malaga, Spain

\begin{abstract}
Breast cancer is the leading cause of mortality in women. It is a heterogeneous disease with a high degree of inter-subject variability even in patients with the same type of tumor, with individualized medicine having acquired significant relevant in this field. The clinical and morphological heterogeneity of the different types of breast tumors has led to a diversity of staging and classification systems. Thus, these tumors show wide variability in genetic expression and prognostic biomarkers. Surgical treatment is essential in the management of these patients. However, the perioperative period has been found to significantly influence survival and cancer recurrence. There is growing interest in the pro-tumoral effect of different anesthetic and analgesic agents used intraoperatively and their relationship with metastatic progression. There is cumulative evidence of the influence of anesthetic techniques on the physiopathological mechanisms of survival and growth of the residual neoplastic cells released during surgery. Prospective randomized clinical trials are needed to obtain quality evidence on the relationship between cancer and anesthesia.
\end{abstract}

This document summarizes the evidence currently available about the effects of the anesthetic agents and techniques used in primary cancer surgery and long-term oncologic outcomes, and the biomolecular mechanisms involved in their interaction..

Keywords: Anesthetic drugs and techniques, opioids, propofol, volatile agent, breast cancer, cancer recurrence, Biomarkers, miRNA.

\section{Introduction}

Breast cancer is the leading cause of mortality in women (1). Even when the tumor is completely resected, tumor recurrence occurs in up to one third of patients, being metastatic disease the direct cause of death (2). Surgery may generate systemic 
inflammatory response syndrome, which causes oxidative stress, which in turn impairs anti-tumor immunologic response (3). Surgical stress activates a neuroendocrine response in the hypothalamic-pituitary-adrenal axis (HPA axis) and sympathetic nervous system (SNS), with results in the suppression of cell-mediated immunity (CMI); this suppression is induced by the release of neuroendocrine mediators such as catecholamines, cortisol, and cytokines (4).

These mediators, including vascular endothelial growth factor (VEGF), matrix (MMPs) and interleukin (IL) 6 and 8, are endogenous regulators that promote tumor growth and angiogenesis, thereby favoring metastasis. Recent studies reveal that the type of anesthesia administered during cancersurgery may influence the course of the disease. However, (5). there is limited evidence available that supports the modification of standard anesthetic approaches.

Further studies are necessary to identify the mechanisms by which each agent interacts with tumor cells.

\section{Anesthetics and Cancer Relapse \\ 1.- Hypnotics \\ 1.1 Propofol}

Propofol may have beneficial effects on survival in cancer patients, including breast cancer patients. This agent inhibits tumor cell migration and proliferation, promotes tumor apoptosis and has anti-inflammatory activity (5-7). This agent acts on the immune system at the level of natural killer lymphocytes (NK), which belong to innate immunity. Cho et al (8) conducted a prospective study comparing a group of patients who received propofol-ketorolac vs sevoflurane-fentanyl. The authors observed a reduction in NK activity in the sevoflurane group, whereas this activity was increased in the propofol group. Although evidence consistently shows that propofol has tumorkilling activity, two recent studies associate it with pro-tumor activity in breast and bladder cancer, mediated by the activation of the Nrf2 pathway and the reduction of p53 levels $(9,10)$.

Propofol favors tumor cell apoptosis by affecting matrix metalloproteinase (MMPs) expression, which play a crucial role in extracellular protein degradation and epithelialmesenchymal transition (EMT), activate vascular endothelial growth factor (VEGF) (11), and inhibit intrinsic apoptosis pathways (12). Two pathways have been identified to be involved in the inhibition of the synthesis of these proteins: the MAP-kinase pathway (ERK1/2, JNK y p38) in colon cancer (13) and NF-kB in breast cancer (14).

As to the ability to induce tumor apoptosis, several pathways have been investigated, such as the inhibition of anti-apoptosis mechanisms, including Bcl-2, Sox4, Akt/mTOR and $\mathrm{Wnt} / \beta$-catenin and the increase of pathways involving tumor suppressor genes such as Bax, ING3, Fox01 and caspase pathways (15-20).

In addition, Wang et al (21) demonstrated that propofol induces the intrinsic apoptotic signaling pathway by the release of reactive oxygen species (ORS).

Propofol may inhibit surgery-induced SIRS, since it regulates the synthesis, stability and distribution of hypoxia-inducible factor 1 (HIF1A), which is elevated in the tumor micro-environment, which hypoxic conditions promote cell migration and invasion, thereby decreasing cell concentrations (22). Ecimovic et al (23) demonstrated in vitro the role of NET-1 (neuroepithelial cell transforming gene-1) overexpression, a gene that is associated with tumor dissemination and decreases with propofol exposure (24).

\subsection{Halogenated}

Inhalation agents have been suggested to have a tumorigenic effect since they both, inhibit tumor cell apoptosis and stimulate tumor cell proliferation and migration. 
Kawaraguchi et al (25) documented that isoflurane confers a protective effect on tumor cells in colon cancer against TNF-mediated apoptosis (TRAIL or TNF-related apoptosisinducing ligand) by interacting with caveolin-1. This protein has been linked to higher resistance to apoptosis, migration and elevated invasivity in breast cancer cells. More specifically, in advanced breast cancer, elevated caveolin-1 concentrations has been associated with lower survival.

Ecimovic et al (26) analyzed in vitro the ability of isoflurane to stimulate tumor cell proliferation, migration and invasion in patients with positive (ER+) and negative (ER-) estrogen receptor breast cancer (with the latter not having invasive capacity).

Sevoflurane reduces NK activity, thereby reducing immunosurveillance and favoring progression of micrometastases. In contrast, a range of ongoing clinical trials have been conducted to compare immunosuppression induced by halogenated anesthetics vs general intravenous anesthesia, with inconsistent results (27-32). Enlund et al (27) found no significant differences in 1-year and 5-year survival in a sample of 1,837 breast cancer patients. Kim et al (29) compared propofol with a variety of halogenated agents (sevoflurane, desflurane, isoflurane and enflurane), without significant differences. Recent retrospective studies (30-32) provide cumulative evidence of the absence of significant differences between intravenous and inhalation anesthetics in terms of recurrence or survival.

\section{Analgesics \\ 2.1 Opioids}

Opioids have an immunosuppressive effect that influences cellular and humoral immunity, as they reduce NK lymphocyte activity and proliferation, citokine production, phagocytic activity, and antibody release (33). The type and degree of immunosuppression depends on the type, dose and time of exposure to the opioid. All synthetic opioids reduce NK activity (34) (35).

Morphine inhibits T and NK lymphocyte activity, promotes lymphocyte apoptosis, reduces toll-like 4 factor in macrophages (36) and has angiogenic activity (37) . In addition, the tumorigenic activity of morphine is mediated by two independent mechanisms, namely: by direct stimulation of mu receptors in tumor cells, which overexpression has been associated with poor prognosis, and indirectly by promoting neo-angiogenesis through metabolic signaling pathways similar to those used by VEGF factor $(38,39)$.

In breast tumor cells, fentanyl reduces levels of Bax, Bcl2, Oct4, Sox2, and Nanog, which are involved in cell apoptosis and differentiation mechanisms (40). Although tramadol is a $\mu$-receptor agonist, its analgesic effect is prevailingly mediated by the inhibition of noradrenaline and serotonin reuptake. Sacerdote et al (41) assessed the relationship between tramadol and immune response in patients with uterine carcinoma. The authors found that tramadol does not only inhibits but also stimulates NK lymphocyte activity. Later, Xia et al demonstrated in breast tumor cells in vitro that tramadol reduces tumor cell proliferation, migration and invasion by up to 28 days through the inhibition of $\alpha 2$-adrenergic receptor. In a retrospective study, Kim et al (42) observed lower rates of mortality and tumor recurrence in the group of breast cancer patients treated surgically who received tramadol. This effect is conferred by the inhibition of tumor cell proliferation, induction of apoptosis, and action on serotonergic receptors and transient receptor potential channel V1 or TRPV1.

\subsection{Regional anesthesia and local anesthetics}

There is a variety of locoregional anesthesia techniques in breast cancer surgery with good analgesic outcomes. Paravertebral block (PVB) is the most widely used 
technique, although it is associated with a higher risk for severe complications. New techniques have been developed, with pectoral block type II having shown good effectiveness, and being employed in a similar context as PVB (43). Several studies have been published comparing general anesthesia vs combined anesthesia: five retrospective studies, two prospective studies and a systematic review. Studies provide evidence of the beneficial effects of not using opioids and/or local anesthetics per se (44-51).

Exadaktylos et al (44) published the first retrospective study assessing the outcomes of 129 patients with breast cancer treated surgically, of whom 50 received combined anesthesia (PVB+Propofol) and 79 balance general anesthesia. The rate of recurrence was lower in the group that received combined anesthesia. In contrast, a recent systematic review conducted by Pérez-González et al (51) did not show statistically significant differences between combined and general anesthesia.

Local anesthetics block afferent and efferent nerve response and effectively suppress sympathic stimulation through the inhibition of hypothalamic-pituitaryadrenal (HPA) stimulation induced by surgical stress, thereby reducing HPA activity (52).

Lidocaine has been proven to exert beneficial effects in vivo and in vitro, and it is associated with a reduction of tumor cell proliferation, migration and invasion in breast, liver and lung cancer $(53,54)$. Lidocaine inhibits the proto-oncogen that releases Src, an intracellular non- tyrosine kinase protein that is involved in cell proliferation and migration processes through ICAM-1 phosphorylation, which enables neutrophils to cross the endothelium and increase immune response (54). It has been reported to have effects on other signaling pathways such as TRPV-6 inhibition (55) or DNA demethylation in breast cancer cells (56). Chang et al (57) demonstrated in vitro that both, lidocaine and bupivacaine induce breast cancer cell apopotosis by the activation of caspases 7, 8 and 9. In the same line, D'Agositino et al showed that lidocaine inhibits cytoskeletal modification in breast cancer cells (58).

Evidence has been provided that lidocaine infiltration in the peritumoral region inhibits tumor growth by binding EGFR (59). As to the immune system, lidocaine at clinically relevant concentrations stimulates the cytotoxic effect of NK lymphocytes (60). A prospective, randomized trial conducted by Galoș et al revealed that lidocaine reduced neutrophil extracellular traps, a phenomenon that has been associated with tumor recurrence (61).

\subsection{NSAIDs}

The enzyme cyclooxygenase (COX-2) causes an increase of prostaglandins, which are involved in immune system control and angiogenesis. Ketorolac is the most extensively studied NSAID in relation to cancer. It is a COX-1 and COX-2 inhibitor commonly used in the perioperative period. Evidence from retrospective studies demonstrates that perioperative administration of ketorolac reduces breast cancer recurrence by diminishing the production of prostaglandins and VEGF. Forget et al tried to replicate these results in patients with breast cancer at high risk of recurrence (triple negative, neutrophil / lymphocyte ratio $\geq 4$ (62) in a prospective study (63) in 203 patients, without differences having been found between treatment groups.

\section{Dexmedetomidine}

Dexmedetomidine is a selective $\alpha 2$ agonist with sympatholytic and antiinflammatory activity that reduces IL- 6 , IL- 8 and TNF- $\alpha$ concentrations and increases anti-inflammatory cytokine IL-10 levels (64) .

Despite its anti-inflammatory effect, dexmedetomidine is attributed a pro-tumoral activity. Lavon et al (65) demonstrated in animal models that it promotes metastasis in 
breast, lung and colon cancer. This effect is credited to the transient immunosuppression induced by dexmedetomidine, added to the effects of surgical stress and changes in vascular patency.

In the same line, Xia et al (66) investigated the effect of dexmedetomidine in breast cancer cells in vitro and in vivo in mice and concluded that dexmedetomidine promotes tumor cell proliferation, migration and invasion through the inhibition of the $\alpha 2 /$ ERK adrenergic receptor pathway (42).

Cata et al (67) performed a retrospective study involving 1,404 patients with non-small lung cancer (NSCLC) treated surgically to investigate a potential relationship between tumor recurrence and the use of dexmedetomidine. This relationship was not confirmed. Indeed, the results showed a significant relationship between dexmedetomidine and lower survival.

\section{Beta-blockers}

Beta-adrenergic receptors are found both in tumor cells and the immune system (68) and seem to play a key role in carcinogenesis (69) . Beta-blockers have been proven to be involved in angiogenesis and cellular neoproliferation (70) . Exposure to betaagonists inhibits lymphocyte NK activity $(71,72)$ and induces an increase in T-regulator lymphocytes (73), leading to immunosuppression. Kang et al documented that adrenergic stimulation activated the MAP-kinase cascade and, more specifically, the DUSP1 cascade, which causes resistance to chemotherapy and apoptosis.

Recently, Zhou et al (74) observed that propranolol prevented T-regulator lymphocyte elevation. Another potential cellular signaling pathway is adrenergic activation of PI3K/AKT and HIF-1 $\alpha$, which is also inhibited by propranolol (75).

Contradictory results were obtained in five retrospective (76-80) and three cohort studies (80-82) assessing recurrence in breast cancer patients after surgery due to the lack of a standard treatment administration protocol (83-86).

\section{Lipid lowering drugs}

The increased prevalence of cardiovascular disease in the recent years has resulted in an increase in the use of lipid lowering drugs, being statins the most common pharmaceutical group. As a component of the cellular membrane, cholesterol plays an essential role in cellular division; therefore, a reduction in extracellular cholesterol should cause an inhibition of tumor cell proliferation. Cholesterol metabolites such as 27-hydroxycholesterol and 25-hydroxycholesterol may stimulate estrogen receptors (ERs) $(87,88)$. Alikhani et al $(89)$ reported an increase in breast tumor growth mediated by the PI3K/AKT pathway in hyperlipidemic mice.

Cholesterol favors a pro-inflammatory environment by the activation of macrophage toll-like receptors (90) and the inhibition of CCR7 expression in dendritic cells, which explains their antigenic effects (91). On the other hand, cholesterol modulates lymphocyte $\mathrm{T}$ activity through liver $\mathrm{X}$ receptor (LXR) (92).

As to the use of statins, inconsistent results were obtained in six retrospective $(78,93-97)$ and five prospective studies $(83,98-101)$ (four supporting its use and the remainder seven having not provided clinically relevant results). In contrast the three metaanalyses retrieved (102-104) provide consistent evidence that statins reduce breast cancer recurrence. However, these studies were conducted using non-standard methods, and prospective randomized studies are needed.

\section{Biomarkers, anesthetic technique and cancer.}

A multiplicity of anesthetic techniques are used in clinical practice in patients undergoing cancer surgery. The pharmacokinetics and pharmacodynamics of common 
anesthetic agents are thoroughly understood and determine their use based on the characteristics of each patient. Scientific evidence has been recently provided of the effects of anesthetics on the genetic material of cells, as well as on proteins and molecules related to pro-tumor phenomena such as angiogenesis.

The beneficial effects and clinical implications of the different pharmacological groups in cardiovascular surgery are widely known. These include the direct organ protective effects of sevoflurane mediated by the modulation of metabolic cascades (105107).

Targeted therapies based on molecular markers have potential for the diagnosis and prognosis of a diversity of diseases, including cancer. The identification of biomarkers helps better understand the influence of the anesthetic technique on tumor progression and select the optimal anesthetic plan for each cancer patient.

\subsection{Endothelial adhesion molecules}

The main function of endothelial adhesion molecules is mediated by immune response. A range of studies demonstrate that intercellular adhesion molecule-1 (ICAM1) triggers the activation of multiple cellular signaling pathways promoting tumor cell proliferation, migration and resistance to apoptosis, as well as the development of drug resistance induced by cellular adhesion molecules $(108,109)$. Where inflammation occurs, the activated leukocytes adhere to the endothelium through ICAM-1, and cell transmigration follows through vessel walls. A similar mechanism mediates extravasation of circulating tumor cells during metastasis, where endothelial ICAM-1 might play a crucial role (108) .

ICAM-1 is expressed in several types of tumors and by mediation of its main ligand, LFA-1, it may facilitate immunosurveillance (110-112). Several studies associate (49). ICAM-1 expression with a more aggressive tumor phenotype and higher metastatic potential $(112,113)$. The capacity of infiltration of breast cancer cells is related to ICAM-1 expression (109) . Serum levels are elevated in breast cancer patients (114) and correlate with advanced-stage or recurrent disease $(115,116)$ and metastasis.

Schröder et al. documented the association between ICAM-1 mRNA in breast cancer, high levels of urokine plasminogen (uPA) and uPA-1 inhibitor (PAI 1), and Ki67 and VEGF mRNA overexpression (113).

\subsection{Lipocalin 2}

Lipocalin 2 (LCN2), also known as neutrophil gelatinase associated lipocalin (NGAL) regulates angiogenesis $(117,118)$ and has been reported to be elevated in several types of cancer, including breast cancer. The evidence obtained in in vitro and in vivo demonstrates that the tumorigenic and metastatic potential of Lcn2 is induced by TEM promotion, cell migration, invasion, VEGF production, and angiogenesis. The mechanisms that mediate the metastatic and oncogenic potential of Lcn2 include PI3K / Akt / NF- $\mathrm{BB}, \mathrm{HIF}-1 \mathrm{a} / \mathrm{ERK}$ signaling pathways and the protective formation of the MMP-9 / Lcn2 complex (119). When its activity is knocked down, angiogenesis decreases by the inhibition of the MMP-9/Lcn complex, thereby reducing MMP-9 activity and cell migration and invasion capacity $(117,118,120-124)$.

ICAM-targeted Lcn2 sRNA (small interfering RNA) significantly reduced the angiogenic activity and migration of triple-negative breast tumor cells $(125,126)$. Leng et al. report the inhibition of $4 \mathrm{~T} 1$ cellular metastases with the use of anti-Lcn2I policlonal antibodies (127).

\subsection{Neutrophil extracellular traps (NETs)}


Neutrophil extracellular traps (NETosis) form part of immune response to cancer antigens. NETosis originates from neutrophil degranulation, which results in the release of neutrophil contents into the bloodstream, where they can be detected $(128,129)$. NETosis processes have been described in the tumor microenvironment $(130,131)$. Tumor cells can interact direct or indirectly with neutrophils to induce NET production. Intra-and inter-cellular molecular communications generate micro-environments that act as a premetastatic niche to recruit primary tumor cells and form multiple metastases $(132,133)$.

Park et al described the relationship between metastatic cancer and NET formation by the use of anti-G-CSF blocking antibodies, which reduce the ability of $4 \mathrm{~T} 1$ cells to induce NETosis (134).

Close cooperation between tumor cells, neutrophils and NETosis in the tumor microenvironment demonstrate the role of NETosis in cancer progression and metastasis $(131,135,136)$. The myeloperoxidase enzyme (MPO) and citrullinated histone-3 are specific proteins released during NETosis and can be easily measured in serum (131).

The release of chromatin by tumor cells and neutrophils influence tumor progression and thrombosis associated with cancer (137).

This phenomenon is associated with poor prognosis in esophageal cancer and a higher risk for tumor infiltration in patients with higher NETosis activity (138). Several randomized clinical trials have been conducted to assess the influence of different anesthetic techniques in NETosis. Aghamelu et al. found no significant differences between the halogenated agents vs propofol in patients with breast cancer treated surgically (139).

Then, Galos et al incorporated the differential use of intravenous lidocaine in their treatment protocol and observed significant differences in NETosis markers between groups (61).

\section{4 miRNAs and drugs used during anesthetic procedures}

There is growing interest in the identification of biomarkers for assessing individual risk of cancer progression and response to treatment. MicroRNAs (miRNAs) are endogenous non-coding RNA sequences that regulate gene expression and suppress or activate multiple genes at pre- and post-transcriptional level $(140,141)$. In the recent years, evidence has accumulated of the relevant role of miRNA in the molecular mechanisms of carcinogenesis in healthy patients (142-145). Although these changes are detectable in tumor tissue, levels of deregulated miRNAs can also be determined in blood (146). Likewise, there is wide inter-subject variability in deregulated miRNA levels in healthy subjects and in cancer patients treated surgically (147).

Current evidence suggests that the beneficial or deleterious effects of anesthetics during cancer surgery are mediated by genetic and molecular mechanisms (148). Multiple studies have been published on the interaction of propofol with the genetic mechanisms that mediate miRNA suppression/ overexpression in different types of tumors: propofol increases miRNA let7 expression and apoptosis in ovarian cancer cells (149); it increases miRNA 218 and miRNA 451 expression, thereby resulting in the reduction of MMP-2 expression and cellular proliferation (150) . Finally, propofol reduces the invasive capacity of liver cell carcinoma through miRNA-199a and its action on MMP-9 (151).

Sun et al. concluded that propofol reduces miRNA-374a expression and modulates forkhead box $\mathrm{O} 1$ pathway response to reduce proliferation and resistance to cisplatin in ovarian cancer cells (152).

Propofol has demonstrated in vitro and in vivo it ability to facilitate sensitivization to trastuzumab-resistant tumor cells through epigenetic changes mediated by the miRNA149-5p/IL-6 axis (153). Propofol induces apoptosis in breast cancer cell lines by the inactivation of the miRNA-24/p27 signaling pathway (154) . MiRNA-21 is overexpressed 
in early stage pancreatic cancer. The action of propofol on miRNA-21 involves the suppression of Slugh expression, thereby increasing the proapoptotic effect of the p53 gene and inducing e-cadherin overexpression (155).

Buschmann et al. recently published the first prospective study comparing serum of patients with colon cancer treated surgically and exposed to propofol or sevoflurane and miRNA expression patterns. Significant differences were observed between groups, with propofol showing an inhibitory effect on signaling pathways involved in carcinogenesis (156).

Deng et al. exposed breast cancer cell lines to sevofluorane vs propofol, and observed an increase in tumor survival in the propofol group, mediated by the modulation of intracellular calcium homeostasis (157). In contrast, Liu et al. observed that sevoflurane suppressed breast cancer cell proliferation through an increase in miRNA-203 overexpression (158). Its potential anti-tumor activity is demonstrated by miRNA-155 suppression in papillary thyroid carcinoma (159).

Interactions have been observed in other drugs commonly used in clinical practice. $\mathrm{Li}$ et al. documented that ropivacaine inhibits cellular viability and induces apoptosis, whereas concomitant use of sufentanil mitigates its action by means of miRNA-182$5 p / B C L 10 / C Y C S$ regulation (160). Qu et al. suggest that the beneficial effects of lidocaine on colorectal cancer could be mediated by the upregulation of miRNA-520 a-3p and targeting EGFR (161).

Sequencing of the genome of macrophages treated with morphine shows a differential expression pattern of 26 miRNAs. Of these, miRNA-15b-5p and miRNA$181 \mathrm{~b}-5 \mathrm{p}$ are involved in inflammatory and infectious processes, thereby promoting the suppression of immune functions (162). A diversity of studies reveals the upregulation of 9 miRNAs and downregulation of 17 miRNAs. More specifically, the miRNAs of the Let-7 family have been found to be associated with the MOR pathway (163-165). Low doses of morphine promote non-differentiated cell proliferation, then reducing miRNA$133 \mathrm{~b}$ expression. In contrast, at high doses, they have opposite effects and reduce miRNA-133b and miRNA-128 levels; this effect cannot be countered by naloxone, which suggests and independent mediation by MOR (166). Exposure to morphine upregulates miRNA-543 expression and contributes to tumor progression through MARCKs inhibition (167).

\subsubsection{MiRNAs and breast cancer.}

Different studies document the association between breast cancer and a variety of miRNA expression patterns, which enables the analysis, classification and characterization of different types of tumors (168-170). Mar-Aguilar et al. reported the potential usefulness of three miARNs in breast cancer screening (171). The anti-tumor effect of propofol and pro-tumor effect of sevoflurane have been demonstrated in in vitro studies. These effects are mediated by the modulation of miRNA- 24/p27 and miRNA-203 expression, respectively $(154,158)$.

\subsubsection{MiRNA-21}

There is consistent evidence supporting the oncogenic role of miR-21, which is involved in the inhibition of tumor cell apoptosis and contributes to tumor growth. MiR21 is significantly overexpressed in a wide variety of solid tumors, including breast cancer. MiR-21 overexpression has been associated with tumor progression and poor prognosis (172). It is involved in the inhibition of tropomyosin alpha-1, the TP53 and TAp63 pathways (regulating LKB1 transcription) (173), programmed cell death 4 (related to apoptosis) (174) , a phosphatase tensin homolog (PTEN) (175-178). 
In vitro studies reveal that miR-21 is overexpressed in tissue and cells of triplenegative breast cancer models. This confirms its relationship with MDA-MB-468 cell proliferation and invasion, and the regulation of PTEN expression (179). MiR-21 knockdown reduced proliferation, viability and invasivity, demonstrating that PTEN is a target of this mRNA (180). Its overexpression is also linked to poor survival due to the development of resistance to trastuzumab (181-183).

\subsubsection{MicroRNA-202}

MiR-202 has been recently associated with multiple types of cancer, including breast cancer. It belongs to the Let-7 miRNA family, and its underexpression has been associated with poor differentiation and higher tumor aggressiveness (184).

The let-7 family regulates estrogen receptor alpha in breast cancer growth (185) and is involved in self-renovation and tumorigenicity of breast cancer cells (186) . Joosse et al. detected a relationship between miR-202 levels and prognosis, which suggests a potential role in tumor staging (187).

\subsubsection{MicroRNA-155}

miRNA-155 is involved in immune function by the production of cytokines and cancer development. It is overexpressed in different types of cancer, including breast, liver, uterine and lung cancer (188-190). It favors breast cancer progression by acting on TP53 $(191,192)$ and accelerating metastasis through tumor protein p53-inducible nuclear protein 1 (TP53INP1) (193).

\section{Conclusions}

Perioperative use of anesthetic / analgesic techniques with protective effects on antimetastatic immune response may reduce tumor progression. A limitation of most studies published to data is that they were performed in vitro, where conditions are not the same as in vivo. The use of biomarkers could be useful to indentificate high risk of cancer progression. Randomized clinical trials are required to investigate whether anesthetic / analgesic techniques and anesthetic agent are effective in reducing cancer relapse and increasing survival in oncological patients.

\section{Conflict if interest}

The authors declare no conflict of interest, financial or other- wise.

\section{References}

1. Yan T, Zhang GH, Cheng YZ, Wu LX, Liu XY, Sun YL, et al. Effects of anesthetic technique and surgery on myeloidderived suppressor cells and prognosis in women who underwent breast cancer surgery: A prospective study. Cancer Manag Res [Internet]. 2019 [cited 2021 Mar 22];11:5513-22. Available from: https://pubmed.ncbi.nlm.nih.gov/31417304/ 2. Kim R. Effects of surgery and anesthetic choice on immunosuppression and cancer recurrence [Internet]. Vol. 16, Journal of Translational Medicine. BioMed Central Ltd.; 2018 [cited 2021 Mar 21]. p. 1-13. Available from: https://doi.org/10.1186/s12967-018-1389-7

3. Horowitz M, Neeman E, Sharon E, Ben-Eliyahu S. Exploiting the critical perioperative period to improve long-term cancer outcomes. Nat Rev Clin Oncol. 2015;12(4):213. 
4. Hiller JG, Perry NJ, Poulogiannis G, Riedel B, Sloan EK. Perioperative events influence cancer recurrence risk after surgery [Internet]. Vol. 15, Nature Reviews Clinical Oncology. Nature Publishing Group; 2018 [cited 2021 Mar 22]. p. 205-18. Available from: https://pubmed.ncbi.nlm.nih.gov/29283170/

5. Li R, Liu H, Dilger JP, Lin J. Effect of Propofol on breast Cancer cell, the immune system, and patient outcome [Internet]. Vol. 18, BMC Anesthesiology. BioMed Central Ltd.; 2018 [cited 2021 Mar 19]. p. 77. Available from: https://bmcanesthesiol.biomedcentral.com/articles/10.1186/s12871-018-0543-3

6. Jiang S, Liu Y, Huang L, Zhang F, Kang R. Effects of propofol on cancer development and chemotherapy: Potential mechanisms. Eur J Pharmacol [Internet]. 2018 Jul 15 [cited 2021 Mar 19];831:46-51. Available from: https://linkinghub.elsevier.com/retrieve/pii/S0014299918302218

7. Xu Y, Pan S, Jiang W, Xue F, Zhu X. Effects of propofol on the development of cancer in humans [Internet]. Vol. 53, Cell Proliferation. Blackwell Publishing Ltd; 2020 [cited 2021 Mar 19]. Available from: /pmc/articles/PMC7445405/

8. Cho JS, Lee MH, Kim S Il, Park S, Park HS, Oh E, et al. The effects of perioperative anesthesia and analgesia on immune function in patients undergoing breast cancer resection: A prospective randomized study. Int J Med Sci. 2017 Aug 18;14(10):970-6.

9. Zhang L, Wang N, Zhou S, Ye W, Jing G, Zhang M. Propofol induces proliferation and invasion of gallbladder cancer cells through activation of Nrf2. J Exp Clin Cancer Res [Internet]. 2012 [cited 2021 Mar 19];31(1):66. Available from:/pmc/articles/PMC3502506/

10. Chao M, Linlin S, Juan W, Li D, Liu Y, Cui X. Propofol induces proliferation partially via downregulation of p53 protein and promotes migration via activation of the Nrf2 pathway in human breast cancer cell line MDA-MB-231. Oncol Rep [Internet]. 2017 Feb 1 [cited 2021 Mar 19];37(2):841-8. Available from: http://www.spandidospublications.com/10.3892/or.2016.5332/abstract

11. Gialeli C, Theocharis AD, Karamanos NK. Roles of matrix metalloproteinases in cancer progression and their pharmacological targeting. FEBS J [Internet]. 2011 Jan 1 [cited 2021 Mar 19];278(1):16-27. Available from: http://doi.wiley.com/10.1111/j.1742- 4658.2010.07919.x

12. Mitsiades N, Yu WH, Poulaki V, Tsokos M, Stamenkovic I. Matrix metalloproteinase-7- mediated cleavage of Fas ligand protects tumor cells from chemotherapeutic drug cytotoxicity. Cancer Res. 2001;61(2):577-81.

13. Miao Y, Zhang Y, Wan H, Chen L, Wang F. GABA-receptor agonist, propofol inhibits invasion of colon carcinoma cells. Biomed Pharmacother [Internet]. 2010 Nov 4 [cited 2021 Mar 19];64(9):583-8. Available from: https://linkinghub.elsevier.com/retrieve/pii/S0753332210000788

14. Li Q, Zhang L, Han Y, Jiang Z, Wang Q. Propofol reduces MMPs expression by inhibiting NF- $\kappa$ B activity in human MDA-MB-231 cells. Biomed Pharmacother [Internet]. 2012 Feb [cited 2021 Mar 21];66(1):52-6. Available from: https://pubmed.ncbi.nlm.nih.gov/22264881/

15. Zhang Z, Zang M, Wang S, Wang C. Effects of propofol on human cholangiocarcinoma and the associated mechanisms. Exp Ther Med [Internet]. 2019 Jan 1 [cited 2021 Mar 21];17(1):472-8. Available from: /pmc/articles/PMC6307446/

16. Kang FC, Wang SC, So EC, Chang MM, Wong KL, Cheng KS, et al. Propofol may increase caspase and MAPK pathways, and suppress the Akt pathway to induce apoptosis in MA10 mouse Leydig tumor cells. Oncol Rep [Internet]. 2019 Jun 1 [cited 2021 Mar 21];41(6):3565-74. Available from: http://www.spandidospublications.com/10.3892/or.2019.7129/abstract

17. Chen L, Wan Y, Liu Y, Li T. Propofol inhibits biological functions of leukaemia stem and differentiated cells through suppressing Wnt/ $\beta$-catenin and Akt/mTOR. Clin Exp Pharmacol Physiol [Internet]. 2020 Jan 1 [cited 2021 Mar 21];47(1):127-34. Available from: https://pubmed.ncbi.nlm.nih.gov/31429973/

18. Yang C, Gao J, Yan N, Wu B, Ren Y, Li H, et al. Propofol inhibits the growth and survival of gastric cancer cells in vitro through the upregulation of ING3. Oncol Rep [Internet]. 2017 Jan 1 [cited 2021 Mar 21];37(1):587-93. Available from: https://pubmed.ncbi.nlm.nih.gov/27840947/

19. Gao C, Ren C, Liu Z, Zhang L, Tang R, Li X. GAS5, a FoxO1-actived long noncoding RNA, promotes propofolinduced oral squamous cell carcinoma apoptosis by regulating the miR-1297-GSK3 $\beta$ axis. Artif Cells, Nanomedicine Biotechnol [Internet]. 2019 Dec 4 [cited 2021 Mar 21];47(1):3985-93. Available from: https://pubmed.ncbi.nlm.nih.gov/31583913/

20. Du Q, Liu J, Zhang X, Zhang X, Zhu H, Wei M, et al. Propofol inhibits proliferation, migration, and invasion but promotes apoptosis by regulation of Sox4 in endometrial cancer cells. Brazilian J Med Biol Res [Internet]. 2018 [cited 2021 Mar 21];51(4). Available from: https://pubmed.ncbi.nlm.nih.gov/29490000/

21. Wang H, Zhao L, Wu J, Hong J, Wang S. Propofol induces ROS-mediated intrinsic apoptosis and migration in triple-negative breast cancer cells. Oncol Lett [Internet]. 2020 Jul 1 [cited 2021 Mar 21];20(1):810-6. Available from: http://www.spandidos-publications.com/10.3892/ol.2020.11608/abstract 
22. Tanaka T, Takabuchi S, Nishi K, Oda S, Wakamatsu T, Daijo H, et al. The intravenous anesthetic propofol inhibits lipopolysaccharide-induced hypoxia-inducible factor 1 activation and suppresses the glucose metabolism in macrophages. J Anesth [Internet]. 2010 Feb [cited 2021 Mar 21];24(1):54-60. Available from: https://pubmed.ncbi.nlm.nih.gov/20039079/

23. Ecimovic P, Murray D, Doran P, McDonald J, Lambert DG, Buggy DJ. Direct effect of morphine on breast cancer cell function in vitro: Role of the NET1 gene. Br J Anaesth [Internet]. 2011 [cited 2021 Mar 21];107(6):916-23. Available from: https://pubmed.ncbi.nlm.nih.gov/21857017/

24. Ecimovic P, Murray D, Doran P, Buggy DJ. Propofol and bupivacaine in breast cancer cell function in vitro - Role of the NET1 gene. Anticancer Res. 2014;34(3):1321-31.

25. Kawaraguchi Y, Horikawa YT, Murphy AN, Murray F, Miyanohara A, Ali SS, et al. Volatile anesthetics protect cancer cells against tumor necrosis factor-related apoptosis- inducing ligand-induced apoptosis via caveolins. Anesthesiology [Internet]. 2011 Sep [cited 2021 Mar 21];115(3):499-508. Available from: https://pubmed.ncbi.nlm.nih.gov/21862885/

26. Ecimovic P, McHugh B, Murray D, Doran P, Buggy D. Direct effect of sevoflurane on breast cancer cell function in vitro: BAPCPC1-1. Eur J Anaesthesiol I EJA [Internet]. 2010;27(47). Available from: https://journals.lww.com/ejanaesthesiology/Fulltext/2010/06121/Direct_effect_of_sevoflurane_on_breast_cancer_cell.1. aspx

27. Enlund M, Berglund A, Andreasson K, Cicek C, Enlund A, Bergkvist L. The choice of anaesthetic-sevoflurane or propofol-and outcome from cancer surgery: A retrospective analysis. Ups J Med Sci [Internet]. 2014 [cited 2021 Mar 21];119(3):251-61. Available from: https://pubmed.ncbi.nlm.nih.gov/24857018/

28. Lee JH, Kang SH, Kim Y, Kim HA, Kim BS. Effects of propofol-based total intravenous anesthesia on recurrence and overall survival in patients after modified radical mastectomy: A retrospective study. Korean J Anesthesiol [Internet]. 2016 Apr 1 [cited 2021 Mar 21];69(2):126-32. Available from:https://pubmed.ncbi.nlm.nih.gov/27066202/

29. Kim MH, Kim DW, Kim JH, Lee KY, Park S, Yoo YC. Does the type of anesthesia really affect the recurrence-free survival after breast cancer surgery? Oncotarget [Internet]. 2017 [cited 2021 Mar 21];8(52):90477-87. Available from: https://pubmed.ncbi.nlm.nih.gov/29163846/

30. Yoo S, Lee HB, Han W, Noh DY, Park SK, Kim WH, et al. Total intravenous anesthesia versus inhalation anesthesia for breast cancer surgery: A retrospective cohort study. Anesthesiology [Internet]. 2019 Jan 1 [cited 2021 Mar 21];130(1):31-40. Available from: https://pubmed.ncbi.nlm.nih.gov/30376457/

31. Huang YH, Lee MS, Lou YS, Lai HC, Yu JC, Lu CH, et al. Propofol-based total intravenous anesthesia did not improve survival compared to desflurane anesthesia in breast cancer surgery. PLoS One [Internet]. 2019 Nov 1 [cited 2021 Mar 21];14(11). Available from: https://pubmed.ncbi.nlm.nih.gov/31697743/

32. Shiono S, Shibata SC, Kabata D, Shintani A, Ikeda T, Fujino Y. Comparison of 1-year recurrence-free survival between sevoflurane and propofol use for general anesthesia management in primary breast cancer surgery. J Anesth [Internet]. 2020 Oct 1 [cited 2021 Mar 21];34(5):694-701. Available from: https://pubmed.ncbi.nlm.nih.gov/32524294/

33. Snyder GL, Greenberg S. Effect of anaesthetic technique and other perioperative factors on cancer recurrence [Internet]. Vol. 105, British Journal of Anaesthesia. Oxford University Press; 2010 [cited 2021 Mar 21]. p. 106-15. Available from: https://pubmed.ncbi.nlm.nih.gov/20627881/

34. Gong L, Qin Q, Zhou L, Ouyang W, Li Y, Wu Y, et al. Effects of fentanyl anesthesia and sufentanil anesthesia on regulatory T cells frequencies. Int J Clin Exp Pathol [Internet]. 2014 [cited 2021 Mar 21];7(11):7708-16. Available from: www.ijcep.com/

35. Sacerdote P, Gaspani L, Rossoni G, Panerai AE, Bianchi M. Effect of the opioid remifentanil on cellular immune response in the rat. Int Immunopharmacol [Internet]. 2001 [cited 2021 Mar 21];1(4):713-9. Available from: https://pubmed.ncbi.nlm.nih.gov/11357883/

36. Franchi S, Moretti S, Castelli M, Lattuada D, Scavullo C, Panerai AE, et al. Mu opioid receptor activation modulates Toll like receptor 4 in murine macrophages. Brain Behav Immun [Internet]. 2012 Mar [cited 2021 Mar 21];26(3):480-8. Available from: https://pubmed.ncbi.nlm.nih.gov/22240038/

37. Cheng S, Guo M, Liu Z, Fu Y, Wu H, Wang C, et al. Morphine Promotes the Angiogenesis of Postoperative Recurrent Tumors and Metastasis of Dormant Breast Cancer Cells. Pharmacology [Internet]. 2019 Nov 1 [cited 2021 Mar 21];104(5-6):276-86. Available from: https://pubmed.ncbi.nlm.nih.gov/31494660/

38. Heaney Á, Buggy DJ. Can anaesthetic and analgesic techniques affect cancer recurrence or metastasis? Br J Anaesth [Internet]. 2012 [cited 2021 Mar 21];109(SUPPL1). Available from: https://pubmed.ncbi.nlm.nih.gov/23242747/ 39. Gupta K, Kshirsagar S, Chang L, Schwartz R, Law P-Y, Yee D, et al. Morphine stimulates angiogenesis by activating proangiogenic and survival-promoting signaling and promotes breast tumor growth. Cancer Res. 2002 Aug;62(15):4491-8. 
40. Kocak N, Ozen F, Yildirim IH, Duran Y. Fentanyl inhibits tumorigenesis from human breast stem cells by inducing apoptosis. Asian Pacific J Cancer Prev [Internet]. 2017 Mar 1 [cited 2021 Mar 21];18(3):735-9. Available from: https://pubmed.ncbi.nlm.nih.gov/28441707/

41. Sacerdote P, Bianchi M, Gaspani L, Manfredi B, Maucione A, Terno G, et al. The effects of tramadol and morphine on immune responses and pain after surgery in cancer patients. Anesth Analg [Internet]. 2000 [cited 2021 Mar 21];90(6):1411-4. Available from: https://pubmed.ncbi.nlm.nih.gov/10825330/

42. Xia M, Tong JH, Zhou ZQ, Duan ML, Xu JG, Zeng HJ, et al. Tramadol inhibits proliferation, migration and invasion via $\alpha 2$-adrenoceptor signaling in breast cancer cells. Eur Rev Med Pharmacol Sci [Internet]. 2016 Jan 1 [cited 2021 Mar 21];20(1):157-65. Available from: https://europepmc.org/article/med/26813469

43. Versyck B, van Geffen GJ, Chin KJ. Analgesic efficacy of the Pecs II block: a systematic review and meta-analysis [Internet]. Vol. 74, Anaesthesia. Blackwell Publishing Ltd; 2019 [cited 2021 Mar 22]. p. 663-73. Available from: https://pubmed.ncbi.nlm.nih.gov/30957884/

44. Exadaktylos AK, Buggy DJ, Moriarty DC, Mascha E, Sessler DI. Can anesthetic technique for primary breast cancer surgery affect recurrence or metastasis? Anesthesiology [Internet]. 2006 Oct [cited 2021 Mar 21];105(4):660-4. Available from: https://pubmed.ncbi.nlm.nih.gov/17006061/

45. Starnes-Ott K, Goravanchi F, Meininger JC. Anesthetic Choices and Breast Cancer Recurrence: A Retrospective Pilot Study of Patient, Disease, and Treatment Factors. Crit Care Nurs Q [Internet]. 2015 Dec 1 [cited 2021 Mar 21];38(2):200-10. Available from: https://pubmed.ncbi.nlm.nih.gov/25741961/

46. Kairaluoma P, Mattson J, Heikkilä P, Pere P, Leidenius M. Perioperative Paravertebral Regional Anaesthesia and Breast Cancer Recurrence. Anticancer Res. 2016 Jan;36(1):415-8.

47. Tsigonis AM, Al-Hamadani M, Linebarger JH, Vang CA, Krause FJ, Johnson JM, et al. Are cure rates for breast cancer improved by local and regional anesthesia? Reg Anesth Pain Med [Internet]. 2016 May 1 [cited 2021 Mar 21];41(3):339-47. Available from: https://pubmed.ncbi.nlm.nih.gov/26928797/

48. Cata JP, Chavez-MacGregor M, Valero V, Black W, Black DM, Goravanchi F, et al. The Impact of Paravertebral Block Analgesia on Breast Cancer Survival After Surgery. Reg Anesth Pain Med. 2016;41(6):696-703.

49. Finn DM, Ilfeld BM, Unkart JT, Madison SJ, Suresh PJ, Sandhu NPS, et al. Post- mastectomy cancer recurrence with and without a continuous paravertebral block in the immediate postoperative period: a prospective multi-year followup pilot study of a randomized, triple-masked, placebo-controlled investigation. J Anesth [Internet]. 2017 Jun 1 [cited 2021 Mar 21];31(3):374-9. Available from: https://pubmed.ncbi.nlm.nih.gov/28364165/

50. Sessler DI, Pei L, Huang Y, Fleischmann E, Marhofer P, Kurz A, et al. Recurrence of breast cancer after regional or general anaesthesia: a randomised controlled trial. Lancet [Internet]. 2019 Nov 16 [cited 2021 Mar 21];394(10211):180715. Available from: https://pubmed.ncbi.nlm.nih.gov/31645288/

51. Pérez-González O, Cuéllar-Guzmán LF, Soliz J, Cata JP. Impact of Regional Anesthesia on Recurrence, Metastasis, and Immune Response in Breast Cancer Surgery: A Systematic Review of the Literature [Internet]. Vol. 42, Regional Anesthesia and Pain Medicine. Lippincott Williams and Wilkins; 2017 [cited 2021 Mar 21]. p. 751-6. Available from: https://pubmed.ncbi.nlm.nih.gov/28953508/

52. Kim R. Anesthetic technique and cancer recurrence in oncologic surgery: unraveling the puzzle. Cancer Metastasis Rev [Internet]. 2017 Mar 1 [cited 2021 Mar 21];36(1):159-77. Available from: https://link.springer.com/article/10.1007/s10555-016-9647-8

53. Freeman J, Crowley PD, Foley AG, Gallagher HC, Iwasaki M, Ma D, et al. Effect of perioperative lidocaine, propofol and steroids on pulmonary metastasis in a murine model of breast cancer surgery. Cancers (Basel) [Internet]. 2019 May 1 [cited 2021 Mar 21];11(5). Available from: https://pubmed.ncbi.nlm.nih.gov/31052479/

54. Wall TP, Crowley PD, Sherwin A, Foley AG, Buggy DJ. Effects of Lidocaine and Src Inhibition on Metastasis in a Murine Model of Breast Cancer Surgery. Cancers (Basel) [Internet]. 2019 Sep 22 [cited 2020 Dec 21];11(10):1414. Available from: https://www.mdpi.com/2072-6694/11/10/1414

55. Jiang Y, Gou H, Zhu J, Tian S, Yu L. Lidocaine inhibits the invasion and migration of TRPV6-expressing cancer cells by TRPV6 downregulation. Oncol Lett [Internet]. 2016 Aug 1 [cited 2021 Mar 21];12(2):1164-70. Available from: https://pubmed.ncbi.nlm.nih.gov/27446413/

56. Li K, Yang J, Han X. Lidocaine sensitizes the cytotoxicity of cisplatin in breast cancer cells via up-regulation of RAR 32 and RASSF1A demethylation. Int J Mol Sci [Internet]. 2014 Dec 17 [cited 2021 Mar 21];15(12):23519-36. Available from: https://pubmed.ncbi.nlm.nih.gov/25526566/

57. Chang YC, Liu CL, Chen MJ, Hsu YW, Chen SN, Lin CH, et al. Local anesthetics induce apoptosis in human breast tumor cells. Anesth Analg [Internet]. 2014 Jan [cited 2021 Mar 21];118(1):116-24. Available from: https://pubmed.ncbi.nlm.nih.gov/24247230/ 
58. D’Agostino G, Saporito A, Cecchinato V, Silvestri Y, Borgeat A, Anselmi L, et al. Lidocaine inhibits cytoskeletal remodelling and human breast cancer cell migration. Br J Anaesth [Internet]. 2018 Oct 1;121(4):962-8. Available from: https://doi.org/10.1016/j.bja.2018.07.015

59. Mammoto T, Higashiyama S, Mukai M, Mammoto A, Ayaki M, Mashimo T, et al. Infiltration anesthetic lidocaine inhibits cancer cell invasion by modulating ectodomain shedding of heparin-binding epidermal growth factor-like growth factor (HB-EGF). J Cell Physiol [Internet]. 2002 [cited 2021 Mar 21];192(3):351-8. Available from: https://pubmed.ncbi.nlm.nih.gov/12124780/

60. Ramirez MF, Tran P, Cata JP. The effect of clinically therapeutic plasma concentrations of lidocaine on natural killer cell cytotoxicity. Reg Anesth Pain Med [Internet]. 2015 [cited 2021 Mar 21];40(1):43-8. Available from: https://pubmed.ncbi.nlm.nih.gov/25469757/

61. Galoș E V., Tat T-FF, Popa R, Efrimescu C-II, Finnerty D, Buggy DJ, et al. Neutrophil extracellular trapping and angiogenesis biomarkers after intravenous or inhalation anaesthesia with or without intravenous lidocaine for breast cancer surgery: a prospective, randomised trial. Br J Anaesth [Internet]. 2020 Nov 1 [cited 2021 Mar 21];125(5):712-21. Available from: https://pubmed.ncbi.nlm.nih.gov/32616309/

62. Forget P, Machiels JP, Coulie PG, Berliere M, Poncelet AJ, Tombal B, et al. Neutrophil: Lymphocyte ratio and intraoperative use of ketorolac or diclofenac are prognostic factors in different cohorts of patients undergoing breast, lung, and kidney cancer surgery. Ann Surg Oncol [Internet]. 2013 [cited 2021 Mar 21];20(3 SUPPL.). Available from: https://pubmed.ncbi.nlm.nih.gov/23884751/

63. Forget P, Bouche G, Duhoux FP, Coulie PG, Decloedt J, Dekleermaker A, et al. Intraoperative ketorolac in high-risk breast cancer patients. A prospective, randomized, placebo-controlled clinical trial. PLoS One [Internet]. 2019 Dec 1 [cited 2021 Mar 21];14(12). Available from: https://pubmed.ncbi.nlm.nih.gov/31800611/

64. Li B, Li Y, Tian S, Wang H, Wu H, Zhang A, et al. Anti-inflammatory Effects of Perioperative Dexmedetomidine Administered as an Adjunct to General Anesthesia: A Meta-analysis. Sci Rep [Internet]. 2015 Jul 21 [cited 2021 Mar 21];5. Available from: https://pubmed.ncbi.nlm.nih.gov/26196332/

65. Lavon H, Matzner P, Benbenishty A, Sorski L, Rossene E, Haldar R, et al. Dexmedetomidine promotes metastasis in rodent models of breast, lung, and colon cancers. Br J Anaesth [Internet]. 2018 Jan 1 [cited 2021 Mar 21];120(1):18896. Available from: /pmc/articles/PMC6246773/

66. Xia M, Ji N-N, Duan M-L, Tong J-H, Xu J-G, Zhang Y-M, et al. Dexmedetomidine regulate the malignancy of breast cancer cells by activating $\alpha 2$-adrenoceptor/ERK signaling pathway. Eur Rev Med Pharmacol Sci. 2016 Aug;20(16):3500-6.

67. Cata J, Singh V, Lee B, Villarreal J, Mehran J, Yu J, et al. Intraoperative use of dexmedetomidine is associated with decreased overall survival after lung cancer surgery. J Anaesthesiol Clin Pharmacol [Internet]. 2017 Jul 1 [cited 2021 Mar 21];33(3):317. Available from: http://www.joacp.org/text.asp?2017/33/3/317/214308

68. Cole SW, Sood AK. Molecular pathways: Beta-adrenergic signaling in cancer. Clin Cancer Res [Internet]. 2012 Mar 1 [cited 2021 Mar 21];18(5):1201-6. Available from: https://pubmed.ncbi.nlm.nih.gov/22186256/

69. Phadke S, Clamon G. Beta blockade as adjunctive breast cancer therapy: A review. Vol. 138, Critical Reviews in Oncology/Hematology. Elsevier Ireland Ltd; 2019. p. 173-7.

70. Coelho M, Soares-Silva C, Brandão D, Marino F, Cosentino M, Ribeiro L. $\beta$-Adrenergic modulation of cancer cell proliferation: available evidence and clinical perspectives [Internet]. Vol. 143, Journal of Cancer Research and Clinical Oncology. Springer Verlag; 2017 [cited 2021 Mar 21]. p. 275-91. Available from: https://pubmed.ncbi.nlm.nih.gov/27709364/

71. Shakhar G, Ben-Eliyahu S. In vivo beta-adrenergic stimulation suppresses natural killer activity and compromises resistance to tumor metastasis in rats. J Immunol. 1998 Apr;160(7):3251-8.

72. Chung JF, Lee SJ, Sood AK. Immunological and pleiotropic effects of individual $\beta$ - blockers and their relevance in cancer therapies [Internet]. Vol. 25, Expert Opinion on Investigational Drugs. Taylor and Francis Ltd; 2016 [cited 2021 Mar 21]. p. 501-5. Available from: https://pubmed.ncbi.nlm.nih.gov/26954371/

73. Kohm AP, Sanders VM. Norepinephrine and $\beta 2$-adrenergic receptor stimulation regulate CD4+ $\mathrm{T}$ and $\mathrm{B}$ lymphocyte function in vitro and in vivo. Pharmacological Reviews. 2001.

74. Zhou L, Li Y, Li X, Chen G, Liang H, Wu Y, et al. Propranolol Attenuates Surgical Stress-Induced Elevation of the Regulatory T Cell Response in Patients Undergoing Radical Mastectomy. J Immunol [Internet]. 2016 Apr 15 [cited 2021 Mar 21];196(8):3460-9. Available from: https://pubmed.ncbi.nlm.nih.gov/26969754/

75. Lin Z, Wang L, Huang G, Wang W, Lin H. Propranolol inhibits the activity of PI3K, AKT, and HIF-1 $\alpha$ in infantile hemangiomas. Pediatr Surg Int [Internet]. 2018 Nov 1 [cited 2021 Mar 21];34(11):1233-8. Available from: https://pubmed.ncbi.nlm.nih.gov/30232552/ 
76. Ganz PA, Habel LA, Weltzien EK, Caan BJ, Cole SW. Examining the influence of beta blockers and ACE inhibitors on the risk for breast cancer recurrence: Results from the LACE cohort. Breast Cancer Res Treat [Internet]. 2011 Sep [cited 2021 Mar 21];129(2):549-56. Available from: https://pubmed.ncbi.nlm.nih.gov/21479924/

77. Melhem-Bertrandt A, Chavez-MacGregor M, Lei X, Brown EN, Lee RT, Meric- Bernstam F, et al. Beta-blocker use is associated with improved relapse-free survival in patients with triple-negative breast cancer. J Clin Oncol [Internet]. 2011 Jul 1 [cited 2021 Mar 21];29(19):2645-52. Available from: https://pubmed.ncbi.nlm.nih.gov/21632501/

78. Botteri E, Munzone E, Rotmensz N, Cipolla C, De Giorgi V, Santillo B, et al. Therapeutic effect of $\beta$-blockers in triple-negative breast cancer postmenopausal women. Breast Cancer Res Treat [Internet]. 2013 [cited 2021 Mar 21];140(3):567-75. Available from: https://pubmed.ncbi.nlm.nih.gov/23912960/

79. Sakellakis M, Kostaki A, Starakis I, Koutras A. $\beta$-Blocker Use and Risk of Recurrence in Patients with Early Breast Cancer. Chemotherapy [Internet]. 2015 Nov 5 [cited 2021 Mar 21];60(5-6):288-9. Available from: https://pubmed.ncbi.nlm.nih.gov/25998892/

80. Chen L, Chubak J, Boudreau DM, Barlow WE, Weiss NS, Li CI. Use of antihypertensive medications and risk of adverse breast cancer outcomes in a SEER-Medicare population. Cancer Epidemiol Biomarkers Prev [Internet]. 2017 Nov 1 [cited 2021 Mar 21];26(11):1603-10. Available from: https://pubmed.ncbi.nlm.nih.gov/28807926/

81. Powe DG, Voss MJ, Zänker KS, Habashy HO, Green AR, Ellis IO, et al. Beta-blocker drug therapy reduces secondary cancer formation in breast cancer and improves cancer specific survival. Oncotarget [Internet]. 2010 [cited 2021 Mar 21];1(7):628-38. Available from: https://pubmed.ncbi.nlm.nih.gov/21317458/

82. Sørensen GV, Ganz PA, Cole SW, Pedersen LA, Sørensen HT, Cronin-Fenton DP, et al. Use of $\beta$-blockers, angiotensin-converting enzyme inhibitors, angiotensin II receptor blockers, and risk of breast cancer recurrence: A Danish nationwide prospective cohort study. J Clin Oncol [Internet]. 2013 Jun 20 [cited 2021 Mar 21];31(18):2265-72. Available from: https://pubmed.ncbi.nlm.nih.gov/23650417/

83. Boudreau DM, Yu O, Chubak J, Wirtz HS, Bowles EJA, Fujii M, et al. Comparative safety of cardiovascular medication use and breast cancer outcomes among women with early stage breast cancer. Breast Cancer Res Treat [Internet]. 2014 [cited 2021 Mar 21];144(2):405-16. Available from: https://pubmed.ncbi.nlm.nih.gov/24557337/

84. Li C, Li T, Tang R, Yuan S, Zhang W. $\beta$-blocker use is not associated with improved clinical outcomes in women with breast cancer: A meta-analysis. Biosci Rep [Internet]. 2020 Jun 1 [cited 2021 Mar 21];40(6):20200721. Available from:/pmc/articles/PMC7303345/

85. Childers WK, Hollenbeak CS, Cheriyath P. $\beta$-blockers reduce breast cancer recurrence and breast cancer death: A meta-analysis [Internet]. Vol. 15, Clinical Breast Cancer. Elsevier Inc.; 2015 [cited 2021 Mar 21]. p. 426-31. Available from:https://pubmed.ncbi.nlm.nih.gov/26516037/

86. Ganz PA, Habel LA, Weltzien EK, Caan BJ CS. Is Beta-Blocker Use Beneficial in Breast Cancer? A Meta-Analysis. Oncol. 2017;92(5):264-8.

87. Baek AE, Nelson ER. The Contribution of Cholesterol and Its Metabolites to the Pathophysiology of Breast Cancer [Internet]. Vol. 7, Hormones and Cancer. SpringerusUS; 2016 [cited 2021 Mar 21]. p. 219-28. Available from: https://pubmed.ncbi.nlm.nih.gov/27020054/

88. DuSell CD, Umetani M, Shaul PW, Mangelsdorf DJ, McDonnell DP. 27- Hydroxycholesterol is an endogenous selective estrogen receptor modulator. Mol Endocrinol [Internet]. 2008 Jan [cited 2021 Mar 21];22(1):65-77. Available from: https://pubmed.ncbi.nlm.nih.gov/17872378/

89. Alikhani N, Ferguson RD, Novosyadlyy R, Gallagher EJ, Scheinman EJ, Yakar S, et al. Mammary tumor growth and pulmonary metastasis are enhanced in a hyperlipidemic mouse model. Oncogene [Internet]. 2013 Feb 21 [cited 2021 Mar 21];32(8):961-7.Available from: https://pubmed.ncbi.nlm.nih.gov/22469977/

90. Strachan DC, Ruffell B, Oei Y, Bissell MJ, Coussens LM, Pryer N, et al. CSF1R inhibition delays cervical and mammary tumor growth in murine models by attenuating the turnover of tumor-associated macrophages and enhancing infiltration by CD8+ T cells. Oncoimmunology [Internet]. 2013 [cited 2021 Mar 21];2(12). Available from: https://pubmed.ncbi.nlm.nih.gov/24498562/

91. Villablanca EJ, Raccosta L, Zhou D, Fontana R, Maggioni D, Negro A, et al. Tumor- mediated liver X receptor- $\alpha$ activation inhibits CC chemokine receptor-7 expression on dendritic cells and dampens antitumor responses. Nat Med [Internet]. 2010 Jan [cited 2021 Mar 21];16(1):98-105. Available from: https://pubmed.ncbi.nlm.nih.gov/20037595/

92. Bensinger SJ, Bradley MN, Joseph SB, Zelcer N, Janssen EM, Hausner MA, et al. LXR Signaling Couples Sterol Metabolism to Proliferation in the Acquired Immune Response. Cell [Internet]. 2008 Jul 11 [cited 2021 Mar 21];134(1):97-111. Available from: https://pubmed.ncbi.nlm.nih.gov/18614014/

93. Brewer TM, Masuda H, Liu DD, Shen Y, Liu P, Iwamoto T, et al. Statin use in primary inflammatory breast cancer: A cohort study. Br J Cancer [Internet]. 2013 Jul 23 [cited 2021 Mar 21];109(2):318-24. Available from: https://pubmed.ncbi.nlm.nih.gov/23820253/ 
94. Chae YK, Valsecchi ME, Kim J, Bianchi AL, Khemasuwan D, Desai A, et al. Reduced risk of breast cancer recurrence in patients using ACE inhibitors, ARBs, and/or statins. Cancer Invest [Internet]. 2011 Nov [cited 2021 Mar 21];29(9):585-93. Available from: https://pubmed.ncbi.nlm.nih.gov/21936625/

95. Li YR, Ro V, Steel L, Carrigan E, Nguyen J, Williams A, et al. Impact of long-term lipid-lowering therapy on clinical outcomes in breast cancer. Breast Cancer Res Treat [Internet]. 2019 Aug 13 [cited 2021 Mar 21];176(3):669-77. Available from: http://link.springer.com/10.1007/s10549-019-05267-z

96. Sakellakis M, Akinosoglou K, Kostaki A, Spyropoulou D, Koutras A. Statins and risk of breast cancer recurrence. Breast Cancer Targets Ther [Internet]. 2016 Nov 4 [cited 2021 Mar 21];8:199-205. Available from: https://pubmed.ncbi.nlm.nih.gov/27853392/

97. Shaitelman SF, Stauder MC, Allen P, Reddy S, Lakoski S, Atkinson B, et al. Impact of statin use on outcomes in triple negative breast cancer. J Cancer [Internet]. 2017 [cited 2021 Mar 21];8(11):2026-32. Available from: https://pubmed.ncbi.nlm.nih.gov/28819403/

98. Ahern TP, Pedersen L, Tarp M, Cronin-Fenton DP, Garne JP, Silliman RA, et al. Statin prescriptions and breast cancer recurrence risk: A Danish nationwide prospective cohort study [Internet]. Vol. 103, Journal of the National Cancer Institute. J Natl Cancer Inst; 2011 [cited 2021 Mar 21]. p. 1461-8. Available from: https://pubmed.ncbi.nlm.nih.gov/21813413/

99. Harborg S, Heide-Jørgensen U, Ahern TP, Ewertz M, Cronin-Fenton D, Borgquist S. Statin use and breast cancer recurrence in postmenopausal women treated with adjuvant aromatase inhibitors: a Danish population-based cohort study. Breast Cancer Res Treat [Internet]. 2020 Aug 22 [cited 2021 Mar 21];183(1):153-60. Available from: http://link.springer.com/10.1007/s10549-020-05749-5

100. Kwan ML, Habel LA, Flick ED, Quesenberry CP, Caan B. Post-diagnosis statin use and breast cancer recurrence in a prospective cohort study of early stage breast cancer survivors. Breast Cancer Res Treat [Internet]. 2008 Jun [cited 2021 Mar 21];109(3):573-9. Available from:/pmc/articles/PMC3507509/

101. Tryggvadottir H, Huzell L, Gustbée E, Simonsson M, Markkula A, Jirström K, et al. Interactions between ABCB1genotype and preoperative statin use impact clinical outcomes among breast cancer patients. Front Oncol [Internet]. 2018 Oct 12 [cited 2021 Mar 21];8(OCT):428. Available from: /pmc/articles/PMC6194198/

102. Lv H, Shi D, Fei M, Chen Y, Xie F, Wang Z, et al. Association Between Statin Use and Prognosis of Breast Cancer: A Meta-Analysis of Cohort Studies [Internet]. Vol. 10, Frontiers in Oncology. Frontiers Media S.A.; 2020 [cited 2021 Mar 21]. p. 556243. Available from: /pmc/articles/PMC7596255/

103. Manthravadi S, Shrestha A, Madhusudhana S. Impact of statin use on cancer recurrence and mortality in breast cancer: A systematic review and meta-analysis [Internet]. Vol. 139, International Journal of Cancer. Wiley-Liss Inc.; 2016 [cited 2021 Mar 21]. p.1281-8. Available from: https://pubmed.ncbi.nlm.nih.gov/27176735/

104. Mansourian M, Haghjoo-Javanmard S, Eshraghi A, Vaseghi G, Hayatshahi A, Thomas J. Statins use and risk of breast cancer recurrence and death: A systematic review and meta-analysis of observational studies [Internet]. Vol. 19, Journal of Pharmacy and Pharmaceutical Sciences. Canadian Society for Pharmaceutical Sciences; 2016 [cited 2021 Mar 21]. p. 72-81. Available from: https://pubmed.ncbi.nlm.nih.gov/27096694/

105. Inamura Y, Miyamae M, Sugioka S, Kaneda K, Okusa C, Onishi A, et al. Aprotinin abolishes sevoflurane postconditioning by inhibiting nitric oxide production and phosphorylation of protein kinase $C-\delta$ and glycogen synthase kinase 3ß. J Am Soc Anesthesiol. 2009;111(5):1036-43.

106. Lemoine S, Zhu L, Buléon C, Massetti M, Gérard JL, Galera P, et al. Mechanisms involved in the desfluraneinduced post-conditioning of isolated human right atria from patients with type 2 diabetes. Br J Anaesth. 2011;107(4):510-8.

107. Lemoine S, Zhu L, Beauchef G, Lepage O, Babatasi G, Ivascau C, et al. Role of 70-kDa Ribosomal Protein S6 Kinase, Nitric Oxide Synthase, Glycogen Synthase Kinase-3 $\beta$, and Mitochondrial Permeability Transition Pore in Desflurane-induced Postconditioning in Isolated Human Right Atria. J Am Soc Anesthesiol. 2010;112(6):1355-63.

108. Roland CL, Harken AH, Sarr MG, Barnett Jr CC. ICAM-1 expression determines malignant potential of cancer. Surgery. 2007;141(6):705-7.

109. Rosette C, Roth RB, Oeth P, Braun A, Kammerer S, Ekblom J, et al. Role of ICAM1 in invasion of human breast cancer cells. Carcinogenesis. 2005;26(5):943-50.

110. Maeda K, Kang S-M, Sawada T, Nishiguchi Y, Yashiro M, Ogawa Y, et al. Expression of intercellular adhesion molecule-1 and prognosis in colorectal cancer. Oncol Rep. 2002;9(3):511-4.

111. Tachimori A, Yamada N, Sakate Y, Yashiro M, Maeda K, Ohira M, et al. Up regulation of ICAM-1 gene expression inhibits tumour growth and liver metastasis in colorectal carcinoma. Eur J Cancer. 2005;41(12):1802-10. 
112. Maruo Y, Gochi A, Kaihara A, Shimamura H, Yamada T, Tanaka N, et al. ICAM-1 expression and the soluble ICAM-1 level for evaluating the metastatic potential of gastric cancer. Int J cancer. 2002;100(4):486-90.

113. Schröder C, Witzel I, Müller V, Krenkel S, Wirtz RM, Jänicke F, et al. Prognostic value of intercellular adhesion molecule (ICAM)-1 expression in breast cancer. J Cancer Res Clin Oncol. 2011;137(8):1193-201.

114. Regidor PA, Callies R, Regidor M, Schindler AE. Expression of the cell adhesion molecules ICAM-1 and VCAM-1 in the cytosol of breast cancer tissue, benign breast tissue and corresponding sera. Eur J Gynaecol Oncol. 1998;19(4):377-83.

115. Köstler WJ, Tomek S, Brodowicz T, Budinsky AC, Flamm M, Hejna M, et al. Soluble ICAM-1 in breast cancer: clinical significance and biological implications. Cancer Immunol Immunother [Internet]. 2001;50(9):483-90. Available from: https://doi.org/10.1007/s002620100223

116. O'Hanlon DM, Fitzsimons H, Lynch J, Tormey S, Malone C, Given HF. Soluble adhesion molecules (E-selectin, ICAM-1 and VCAM-1) in breast carcinoma. Eur J Cancer [Internet]. 2002 Nov 1;38(17):2252-7. Available from: https://doi.org/10.1016/S0959-8049(02)00218-6

117. Fernández CA, Yan L, Louis G, Yang J, Kutok JL, Moses MA. The matrix metalloproteinase-9/neutrophil gelatinase-associated lipocalin complex plays a role in breast tumor growth and is present in the urine of breast cancer patients. Clin cancer Res an Off J Am Assoc Cancer Res. 2005 Aug;11(15):5390-5.

118. Yang J, McNeish B, Butterfield C, Moses MA. Lipocalin 2 is a novel regulator of angiogenesis in human breast cancer. FASEB J Off Publ Fed Am Soc Exp Biol. 2013 Jan;27(1):45-50.

119. Yang J, Moses MA. Lipocalin 2: a multifaceted modulator of human cancer. Cell Cycle. 2009 Aug;8(15):2347-52. 120. Yang J, Bielenberg DR, Rodig SJ, Doiron R, Clifton MC, Kung AL, et al. Lipocalin 2 promotes breast cancer progression. Proc Natl Acad Sci U S A. 2009 Mar;106(10):3913-8.

121. Cheng G, Sun X, Wang J, Xiao G, Wang X, Fan X, et al. HIC1 silencing in triple- negative breast cancer drives progression through misregulation of LCN2. Cancer Res. 2014;74(3):862-72.

122. Leng X, Wu Y, Arlinghaus RB. Relationships of lipocalin 2 with breast tumorigenesis and metastasis. J Cell Physiol. 2011;226(2):309-14.

123. Ören B, Urosevic J, Mertens C, Mora J, Guiu M, Gomis RR, et al. Tumour stroma- derived lipocalin-2 promotes breast cancer metastasis. J Pathol. 2016 Jul;239(3):274-85.

124. Hu C, Yang K, Li M, Huang W, Zhang F, Wang H. Lipocalin 2: a potential therapeutic target for breast cancer metastasis. Onco Targets Ther [Internet]. 2018 Nov13;11:8099-106. Available from: https://pubmed.ncbi.nlm.nih.gov/30519052

125. Guo P, Yang J, Jia D, Moses MA, Auguste DT. ICAM-1-Targeted, Lcn2 siRNA- Encapsulating Liposomes are Potent Anti-angiogenic Agents for Triple Negative Breast Cancer. Theranostics [Internet]. 2016 Jan 1;6(1):1-13. Available from: https://pubmed.ncbi.nlm.nih.gov/26722369

126. Guo P, Yang J, Huang J, Auguste DT, Moses MA. Therapeutic genome editing of triple- negative breast tumors using a noncationic and deformable nanolipogel. Proc Natl Acad Sci U S A [Internet]. 2019/08/26. 2019 Sep 10;116(37):18295-303. Available from: https://pubmed.ncbi.nlm.nih.gov/31451668

127. Leng X, Ding T, Lin H, Wang Y, Hu L, Hu J, et al. Inhibition of lipocalin 2 impairs breast tumorigenesis and metastasis. Cancer Res. 2009 Nov;69(22):8579-84.

128. Berger-Achituv S, Brinkmann V, Abu-Abed U, Kühn LI, Ben-Ezra J, Elhasid R, et al. A proposed role for neutrophil extracellular traps in cancer immunoediting. Front Immunol. 2013;4:48.

129. Dąbrowska D, Jabłońska E, Garley M, Ratajczak-Wrona W, Iwaniuk A. New aspects of the biology of neutrophil extracellular traps. Scand J Immunol. 2016;84(6):317-22.

130. Gonzalez-Aparicio M, Alfaro C. Influence of interleukin-8 and neutrophil extracellular trap (NET) formation in the tumor microenvironment: is there a pathogenic role? J Immunol Res. 2019;2019.

131. Snoderly HT, Boone BA, Bennewitz MF. Neutrophil extracellular traps in breast cancer and beyond: current perspectives on NET stimuli, thrombosis and metastasis, and clinical utility for diagnosis and treatment. Breast Cancer Res. 2019;21(1):1-13.

132. Wang W, Zhang J, Zheng N, Li L, Wang X, Zeng Y. The role of neutrophil extracellular traps in cancer metastasis. Clin Transl Med [Internet]. 2020 Oct 1;10(6):e126. Available from: https://doi.org/10.1002/ctm2.126

133. Tang F, Tie Y, Tu C, Wei X. Surgical trauma-induced immunosuppression in cancer: Recent advances and the potential therapies. Clin Transl Med. 2020;10(1):199-223.

134. Park J, Wysocki RW, Amoozgar Z, Maiorino L, Fein MR, Jorns J, et al. Cancer cells induce metastasis-supporting neutrophil extracellular DNA traps. Sci Transl Med. 2016;8(361):361ra138-361ra138. 
135. Cedervall J, Zhang Y, Olsson A-K. Tumor-Induced NETosis as a Risk Factor for Metastasis and Organ Failure. Cancer Res. 2016 Aug;76(15):4311-5.

136. Demers M, Wong SL, Martinod K, Gallant M, Cabral JE, Wang Y, et al. Priming of neutrophils toward NETosis promotes tumor growth. Oncoimmunology. 2016 May;5(5):e1134073.

137. Demers M, Wagner DD. NETosis: a new factor in tumor progression and cancer- associated thrombosis. Semin Thromb Hemost [Internet]. 2014/03/03. 2014 Apr;40(3):277-83. Available from: https://pubmed.ncbi.nlm.nih.gov/24590420

138. Zhang H, Lv H, Weng M, Wang H, Cata JP, Chen W, et al. Preoperative leukocytosis is associated with increased tumor-infiltrating neutrophil extracellular traps and worse outcomes in esophageal cancer. Ann Transl Med. 2020 Apr;8(7):441.

139. Aghamelu O, Buggy P, Smith G, Inzitari R, Wall T, Buggy DJ. Serum NETosis expression and recurrence risk after regional or volatile anaesthesia during breast cancer surgery: A pilot, prospective, randomised single-blind clinical trial. Acta Anaesthesiol Scand [Internet]. 2020 Nov 13;n/a(n/a). Available from: https://doi.org/10.1111/aas.13745

140. Osada H, Takahashi T. MicroRNAs in biological processes and carcinogenesis. Carcinogenesis. 2007;28(1):2-12.

141. Zhang L, Huang J, Yang N, Greshock J, Megraw MS, Giannakakis A, et al. MicroRNAs exhibit high frequency genomic alterations in human cancer. Proc Natl Acad Sci. 2006;103(24):9136-41.

142. Hossain A, Kuo MT, Saunders GF. Mir-17-5p regulates breast cancer cell proliferation by inhibiting translation of AIB1 mRNA. Mol Cell Biol. 2006;26(21):8191-201.

143. Kong W, Yang H, He L, Zhao J, Coppola D, Dalton WS, et al. MicroRNA-155 is regulated by the transforming growth factor $\beta / \mathrm{Smad}$ pathway and contributes to epithelial cell plasticity by targeting RhoA. Mol Cell Biol. 2008;28(22):6773-84.

144. Kloosterman WP, Plasterk RHA. The diverse functions of microRNAs in animal development and disease. Dev Cell. 2006 Oct;11(4):441-50.

145. Stefani G, Slack FJ. Small non-coding RNAs in animal development. Nat Rev Mol Cell Biol. 2008 Mar;9(3):219-30.

146. Heneghan HM, Miller N, Lowery AJ, Sweeney KJ, Newell J, Kerin MJ. Circulating microRNAs as Novel Minimally Invasive Biomarkers for Breast Cancer. Ann Surg [Internet]. 2010;251(3). Available from: https://journals.lww.com/annalsofsurgery/Fulltext/2010/03000/Circulating_microRNAs_as_Novel_Minimally_Invasive .19.aspx

147. Filipów S, Łaczmański Ł. Blood Circulating miRNAs as Cancer Biomarkers for Diagnosis and Surgical Treatment Response. Front Genet [Internet]. 2019 Mar 11;10:169. Available from: https://pubmed.ncbi.nlm.nih.gov/30915102

148. Guo Y, Yang J, Huang Q, Hsueh C, Zheng J, Wu C, et al. Circular RNAs and their roles in head and neck cancers. Mol Cancer. 2019 Mar;18(1):44.

149. Xu S, Lou F, Wu Y, Sun D-Q, Zhang J-B, Chen W, et al. Circulating tumor DNA identified by targeted sequencing in advanced-stage non-small cell lung cancer patients. Cancer Lett. 2016 Jan;370(2):324-31.

150. Peng K, Liu H-Y, Wu S-R, Liu H, Zhang Z-C, Ji F-H. Does Propofol Anesthesia Lead to Less Postoperative Pain Compared With Inhalational Anesthesia?: A Systematic Review and Meta-analysis. Anesth Analg. 2016 Oct;123(4):846-58.

151. Zhang Y, Yang L, Kucherlapati M, Chen F, Hadjipanayis A, Pantazi A, et al. A Pan- Cancer Compendium of Genes Deregulated by Somatic Genomic Rearrangement across More Than 1,400 Cases. Cell Rep. 2018 Jul;24(2):515-27.

152. Sun Y, Peng Y-B, Ye L-L, Ma L-X, Zou M-Y, Cheng Z-G. Propofol inhibits proliferation and cisplatin resistance in ovarian cancer cells through regulating the microRNA374a/forkhead box O1 signaling axis. Mol Med Rep. 2020 Mar;21(3):1471-80.

153. Tian D, Tian M, Ma Z-M, Zhang L-L, Cui Y-F, Li J-L. Anesthetic propofol epigenetically regulates breast cancer trastuzumab resistance through IL-6/miR-149-5p axis. Sci Rep [Internet]. 2020 Jun 1;10(1):8858. Available from: https://pubmed.ncbi.nlm.nih.gov/32483313

154. Yu B, Gao W, Zhou H, Miao X, Chang Y, Wang L, et al. Propofol induces apoptosis of breast cancer cells by downregulation of miR-24 signal pathway. Cancer Biomark. 2018 Feb;21(3):513-9.

155. Liu X, Ranganathan R, Jiang S, Fang C, Sun J, Kim S, et al. A Chimeric Switch- Receptor Targeting PD1 Augments the Efficacy of Second-Generation CAR T Cells in Advanced Solid Tumors. Cancer Res. 2016 Mar;76(6):1578-90.

156. Buschmann D, Brandes F, Lindemann A, Maerte M, Ganschow P, Chouker A, et al. Propofol and Sevoflurane Differentially Impact MicroRNAs in Circulating Extracellular Vesicles during Colorectal Cancer Resection: A Pilot Study. Anesthesiology. 2020 Jan;132(1):107-20.

157. Deng X, Vipani M, Liang G, Gouda D, Wang B, Wei H. Sevoflurane modulates breast cancer cell survival via modulation of intracellular calcium homeostasis. BMC Anesthesiol [Internet]. 2020 Sep 29;20(1):253. Available from: https://pubmed.ncbi.nlm.nih.gov/32993507 
158. Liu J, Yang L, Guo X, Jin G, Wang Q, Lv D, et al. Sevoflurane suppresses proliferation by upregulating microRNA-203 in breast cancer cells. Mol Med Rep [Internet]. 2018;18(1):455-60. Available from: https://doi.org/10.3892/mmr.2018.8949

159. Li Y, Zeng QG, Qiu JL, Pang T, Wang H, Zhang XX. Sevoflurane inhibits the progression of PTC by downregulating miR-155. Eur Rev Med Pharmacol Sci. 2019;12(15):6579-87.

160. Li L, Sun Y, Zhang N, Qiu X, Wang L, Luo Q. By regulating miR-182- 5p/BCL10/CYCS, sufentanil reduces the apoptosis of umbilical cord mesenchymal stem cells caused by ropivacaine. Biosci Trends. 2019 Mar;13(1):49-57.

161. Qu X, Yang L, Shi Q, Wang X, Wang D, Wu G. Lidocaine inhibits proliferation and induces apoptosis in colorectal cancer cells by upregulating mir-520a-3p and targeting EGFR. Pathol Res Pract. 2018 Dec;214(12):1974-9.

162. Dave RS, Khalili K. Morphine treatment of human monocyte-derived macrophages induces differential miRNA and protein expression: Impact on inflammation and oxidative stress in the central nervous system. J Cell Biochem. 2010;110(4):834-45.

163. Wu Q, Zhang L, Law P-Y, Wei L-N, Loh HH. Long-term morphine treatment decreases the association of $\mu$-opioid receptor (MOR1) mRNA with polysomes through miRNA23b. Mol Pharmacol. 2009;75(4):744-50.

164. Melo Z, Ishida C, Goldaraz MD la P, Rojo R, Echavarria R. Novel roles of non-coding RNAs in opioid signaling and cardioprotection. Non-coding RNA. 2018;4(3):22.

165. He Y, Yang C, Kirkmire CM, Wang ZJ. Regulation of opioid tolerance by let-7 family microRNA targeting the $\mu$ opioid receptor. J Neurosci. 2010;30(30):10251-8.

166. Gonzalez-Nunez V, Noriega-Prieto JA, Rodríguez RE. Morphine modulates cell proliferation through mir133b \&amp;mir128 in the neuroblastoma SH-SY5Y cell line. Biochim Biophys Acta. 2014 Apr;1842(4):566-72.

167. Luo J, Chen Y, Xu Y, Tang M, Zhang X. Morphine contributed to the deterioration of cancer via miR543/MARCKS/Fc $\gamma$ R-mediated phagocytosis pathway. J Pharm Pharmacol. 2019 Oct;71(10):1584-98.

168. Chen X, Wang L, Qu J, Guan N-N, Li J-Q. Predicting miRNA-disease association based on inductive matrix completion. Bioinformatics. 2018;34(24):4256-65.

169. Kim S, Dougherty ER, Shmulevich I, Hess KR, Hamilton SR, Trent JM, et al. Identification of Combination Gene Sets for Glioma Classification 1 Supported in part by the Tobacco Settlement Funds as appropriated by the Texas State Legislature, by a generous donation from the Michael and Betty Kadoorie Foundation, and by a grant fro. Mol Cancer Ther. 2002;1(13):1229-36.

170. Lu J, Getz G, Miska EA, Alvarez-Saavedra E, Lamb J, Peck D, et al. MicroRNA expression profiles classify human cancers. Nature. 2005;435(7043):834-8.

171. Mar-Aguilar F, Mendoza-Ramírez JA, Malagón-Santiago I, Espino-Silva PK, Santuario-Facio SK, Ruiz-Flores P, et al. Serum circulating microRNA profiling for identification of potential breast cancer biomarkers. Dis Markers. 2013;34:163-9.

172. Bautista-Sánchez D, Arriaga-Canon C, Pedroza-Torres A, De La Rosa-Velázquez IA, González-Barrios R, Contreras-Espinosa L, et al. The Promising Role of miR-21 as a Cancer Biomarker and Its Importance in RNA-Based Therapeutics. Mol Ther Nucleic Acids [Internet]. 2020/03/13. 2020 Jun 5;20:409-20. Available from: https://pubmed.ncbi.nlm.nih.gov/32244168

173. Papagiannakopoulos T, Shapiro A, Kosik KS. MicroRNA-21 Targets a Network of Key Tumor-Suppressive Pathways in Glioblastoma Cells. Cancer Res [Internet]. 2008 Oct 1;68(19):8164 LP - 8172. Available from:http://cancerres.aacrjournals.org/content/68/19/8164.abstract

174. Asangani IA, Rasheed SAK, Nikolova DA, Leupold JH, Colburn NH, Post S, et al. MicroRNA-21 (miR-21) posttranscriptionally downregulates tumor suppressor Pdcd4 and stimulates invasion, intravasation and metastasis in colorectal cancer. Oncogene [Internet]. 2008;27(15):2128-36. Available from: https://doi.org/10.1038/sj.onc.1210856

175. Frankel LB, Christoffersen NR, Jacobsen A, Lindow M, Krogh A, Lund AH. Programmed cell death 4 (PDCD4) is an important functional target of the microRNA miR-21 in breast cancer cells. J Biol Chem. 2008 Jan;283(2):1026-33.

176. Meng F, Henson R, Wehbe-Janek H, Ghoshal K, Jacob ST, Patel T. MicroRNA-21 regulates expression of the PTEN tumor suppressor gene in human hepatocellular cancer. Gastroenterology [Internet]. 2007/05/21. 2007 Aug;133(2):64758. Available from: https://pubmed.ncbi.nlm.nih.gov/17681183

177. Petrocca F, Visone R, Onelli MR, Shah MH, Nicoloso MS, de Martino I, et al. E2F1- regulated microRNAs impair TGFbeta-dependent cell-cycle arrest and apoptosis in gastric cancer. Cancer Cell. 2008 Mar;13(3):272-86.

178. Zhu S, Si M-L, Wu H, Mo Y-Y. MicroRNA-21 targets the tumor suppressor gene tropomyosin 1 (TPM1). J Biol Chem. 2007 May;282(19):14328-36.

179. Fang H, Xie J, Zhang M, Zhao Z, Wan Y, Yao Y. miRNA-21 promotes proliferation and invasion of triple-negative breast cancer cells through targeting PTEN. Am J Transl Res [Internet]. 2017 Mar 15;9(3):953-61. Available from: https://pubmed.ncbi.nlm.nih.gov/28386324 
180. Si H, Sun X, Chen Y, Cao Y, Chen S, Wang H, et al. Circulating microRNA-92a and microRNA-21 as novel minimally invasive biomarkers for primary breast cancer. J Cancer Res Clin Oncol [Internet]. 2012/09/30. 2013 Feb;139(2):223-9. Available from: https://pubmed.ncbi.nlm.nih.gov/23052693

181. Asaga S, Kuo C, Nguyen T, Terpenning M, Giuliano AE, Hoon DSB. Direct Serum Assay for MicroRNA-21 Concentrations in Early and Advanced Breast Cancer. Clin Chem [Internet]. 2011 Jan 1;57(1):84-91. Available from: https://doi.org/10.1373/clinchem.2010.151845

182. Gong C, Yao Y, Wang Y, Liu B, Wu W, Chen J, et al. Up-regulation of miR-21 mediates resistance to trastuzumab therapy for breast cancer. J Biol Chem. 2011 May;286(21):19127-37.

183. Yadav P, Mirza M, Nandi K, Jain SK, Kaza RCM, Khurana N, et al. Serum microRNA- 21 expression as a prognostic and therapeutic biomarker for breast cancer patients. Tumour Biol [Internet]. 2016 Nov;37(11):1527515282. Available from: https://doi.org/10.1007/s13277-016-5361-y

184. Su J-L, Chen P-S, Johansson G, Kuo M-L. Function and regulation of let-7 family microRNAs. MicroRNA (Shariqah, United Arab Emirates). 2012;1(1):34-9.

185. Zhao Y, Deng C, Wang J, Xiao J, Gatalica Z, Recker RR, et al. Let-7 family miRNAs regulate estrogen receptor alpha signaling in estrogen receptor positive breast cancer. Breast Cancer Res Treat. 2011 May;127(1):69-80.

186. Yu F, Yao H, Zhu P, Zhang X, Pan Q, Gong C, et al. let-7 regulates self renewal and tumorigenicity of breast cancer cells. Cell. 2007 Dec;131(6):1109-23.

187. Joosse SA, Müller V, Steinbach B, Pantel K, Schwarzenbach H. Circulating cell-free cancer-testis MAGE-A RNA, BORIS RNA, let-7b and miR-202 in the blood of patients with breast cancer and benign breast diseases. Br J Cancer [Internet]. 2014/07/01. 2014 Aug 26;111(5):909-17. Available from: https://pubmed.ncbi.nlm.nih.gov/24983365

188. Liu F, Kong X, Lv L, Gao J. MiR-155 targets TP53INP1 to regulate liver cancer stem cell acquisition and selfrenewal. FEBS Lett [Internet]. 2015;589(4):500-6. Available from: http://www.sciencedirect.com/science/article/pii/S0014579315000253

189. Mattiske S, Suetani RJ, Neilsen PM, Callen DF. The oncogenic role of miR-155 in breast cancer. Cancer Epidemiol biomarkers Prev a Publ Am Assoc Cancer Res cosponsored by Am Soc Prev Oncol. 2012 Aug;21(8):1236-43.

190. Thai T-H, Calado DP, Casola S, Ansel KM, Xiao C, Xue Y, et al. Regulation of the Germinal Center Response by MicroRNA-155. Science (80- ) [Internet]. 2007 Apr 27;316(5824):604 LP - 608. Available from: http://science.sciencemag.org/content/316/5824/604.abstract

191. Hemmatzadeh M, Mohammadi H, Jadidi-Niaragh F, Asghari F, Yousefi M. The role of oncomirs in the pathogenesis and treatment of breast cancer. Biomed Pharmacother. 2016;78:129-39.

192. Kim S, Song JH, Kim S, Qu P, Martin BK, Sehareen WS, et al. Loss of oncogenic miR- 155 in tumor cells promotes tumor growth by enhancing C/EBP- $\beta$-mediated MDSC infiltration. Oncotarget. 2016;7(10):11094.

193. Li N, Cui T, Guo W, Wang D, Mao L. MiR-155-5p accelerates the metastasis of cervical cancer cell via targeting TP53INP1. Onco Targets Ther [Internet]. 2019 Apr 29;12:3181-96. 